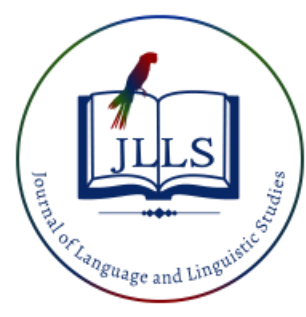

Available online at www.jlls.org

JOURNAL OF LANGUAGE AND LINGUISTIC STUDIES

ISSN: $1305-578 \mathrm{X}$

Journal of Language and Linguistic Studies, 16(3), 1368-1386; 2020

\title{
The reflection of the first foreign language (English) by utilizing translanguaging strategies in the teaching of second foreign language (German)
}

\author{
Gülbin Dağhan-Aslan a iD, Gülay Kıray ${ }^{1}$ b iD \\ a İstanbul, Turkey \\ ${ }^{b}$ İstanbul University-Cerrahpaşa, İstanbul, Turkey
}

\author{
APA Citation: \\ Dağhan - Aslan, G.., \& Kiray, G. (2020). The Reflection of the First Foreign Language (English) by Utilizing Translanguaging Strategies in \\ the Teaching of Second Foreign Language (German). Journal of Language and Linguistic Studies, 16(3), 1368-1386. \\ Submission Date: 05/04/2020 \\ Acceptance Date: 17/08/2020
}

\begin{abstract}
The present study aims to identify translanguaging strategies and question the effectiveness of these strategies in foreign language classrooms. To this aim, a 10th grade German class was observed during fall and spring semesters of 2017-2018 academic year, and interviews before, during and after observation process were conducted with the German language teacher of the second foreign language classroom. Based on the studies of the City University of New York, to provide half of the instruction in English while the other half in the target language through translanguaging strategies is quite beneficial and fruitful for foreign language learning. Translanguaging as an emerging application is accepted as a part of both education and language equality. By challenging the rigid separation of foreign languages in the classroom, translanguaging strategies ensure that teachers employ a 50-50 model of first foreign language and target foreign language while teaching an additional foreign language. Findings of the current research showed that the teacher frequently prefers using vocabulary and syntax-based strategies in her second foreign language classroom, and the students generally responded to the use of these strategies and used them to participate activities and raise questions. Considering specifically the interview transcriptions, it was detected that the teacher uses translanguaging strategies undeliberately, but willingly, without any planning.
\end{abstract}

(C) 2020 JLLS and the Authors - Published by JLLS.

Keywords: translanguaging; translanguaging strategies; foreign language education; first foreign language; second foreign language

\section{Introduction}

Although there is still a strong belief that today's global village is made up of so many monolinguals, composing the majority of the World, the reality is yet totally incompatible with this stereo-typical idea. Thus, most researchers today agree that bi/multilinguals constitute the majority population in the world (Baker, 1995; Turnbull, 2016). Recently, individual multilingualism is being promoted by multifarious factors such as 'the linguistic super-diversity of a country, specific social, cultural, or religious attitudes

\footnotetext{
${ }^{1}$ Corresponding author. Tel.:

E-mail address: gkiray@istanbul.edu.tr
} 
(Tucker, 1998, p.4), international contacts (Hammarberg, 2010), enormous exposure of mixed languages via media (Hammarberg \& Williams, 2009), and transculturation' (Brady \& Shinohara, 2000). Still, many school systems have been offering strict measures and conditions for bilinguals that effectively keep out them from a meaningful education and besides, they are guaranteeing access to monolingual education by adding a separate foreign language in curriculum. However, encouraging an increasing diversity in language classes without clear cut of the boundaries seems like a must in the globe.

In many countries in the globe, like in Turkey, the teenager foreign language learners are at stake, and they become half language learners during their language education life. Learners have been learning several languages in a monolingual path, that is, the target language of learners (first language or first foreign language) is only in use while the others (second or third foreign language) are ignored during their education life.

Referring to the relevant literature, it could be said that language learning process becomes disappointing for such learners since they suffer from keeping their languages active, and most often, their previous learning fossilizes. Thus, dynamic bilingualism as a new concept fills the gaps and offers educators to engage or combine the target language with other languages by activating linguistic repertoire of the bi/multilinguals (Cenoz, 2009; Charambolous \& Rampton, 2012; Garcia \& Wei, 2014).

A considerable amount of research has been carried out to provide better language education for bilinguals, but there is still lack of sufficient language teaching procedure for lifelong foreign language learners, and especially in Turkey it is an obstacle to find an interest in teaching of both or more languages in the same classroom. Therefore, the main aim of the present study is to trace the existence of translanguaging and its strategies which enable learners to utilize their both or more foreign languages consciously in an intermingled way while they are acquiring more than one language together.

\subsection{Literature review}

Due to hybrid but fluid, as well as divergent interactions of the agents, a number of new terms have appeared for language and also for foreign language education, such as 'flexible bilingualism' (Creese \& Blackledge, 2010), 'code-meshing' (Canagarajah, 2011a), 'contemporary urban vernaculars' (Rampton, 2011), 'metrolingualism' (Otsuji \& Pennycook, 2011), 'polylingual languaging' (Jørgensen, Karrebæk, Madsen \& Møller., 2011; Madsen, 2014), 'translingual practice' (Canagarajah, 2013), and 'translanguaging' (García, 2009). From these new terms, 'translanguaging' is the one most giving voice to a learner to activate his/her full range of linguistic repertoires.

In translanguaging, there are not two separate languages that are cognitively activated or deactivated with the demands of the context of communication, but separate and unique features of languages activate one another (Otheguy, García, \& Reid, 2015)

\subsubsection{Translanguaging and translanguaging practices}

Those terms of bilingualism introduced above came together and approved the importance and need of 'translanguaging' (García \& Wei, 2014) or 'translingual practices' (Canagarajah, 2013) in education. Translingualism is defined as transferring among all the languages known by using any linguistic forms that help the users accomplish making meaning with others (Canagarajah, 2011b)

The term 'translanguaging' emerged in the 1980s in Bangor, north Wales, while Cen Williams and his colleagues were investigating practices for bilingual students to use their two languages (Welsh and English) in an only course. They came up with the term 'trawsieithu' to portray the practice of reading or hearing input in one language (e.g. English) and speaking about it in another language as an output (e.g. Welsh, or vice versa) (as cited in Garcia \& Lin, 2016, p.2). Since then, this Welsh term was translated into English as 'translanguaging' and it expanded to cover the active use of multiple languages 
in many contexts and it was redefined by many scholars (García, 2009; Blackledge \& Creese, 2014; Canagarajah, 2011a; 2011b, 2013; García \& Sylvan, 2011; Wei, 2011; Hornberger \& Link, 2012a; Lewis, Jones \& Baker, 2012). It means the process of gaining understanding of the world through the use of all languages that individuals acquire and know (Lewis et al., 2012). Besides, Lewis et al. (2012) emphasized that both or more languages might be activated in the process of learning in a dynamic and functionally integrated manner

Creese and Blackledge (2010) utilized translanguaging to describe a wide range of flexible bilingual practices for language teaching and learning in their research conducted at Bengali, Chinese, Gujarati, and Turkish complementary schools in Britain. They argued for getting rid of monolingual way of instruction, and teaching bilingual children by means of bilingual instructional strategies. According to them, translanguaging does not signify two separate languages, nor a discrete synthesis of dissimilar language practices. Instead, it refers to new language practices that make the complexity of language exchanges among people with disparate backgrounds visible.

On the other hand, Otheguy, García, and Reid (2015) defined translanguaging as follows: "the deployment of a speaker's full linguistic repertoire without regard for watchful adherence to the socially and politically defined boundaries of named languages" (p.283). García (2009) is the first scholar rigorously elaborated and extended translanguaging in minorized pedagogical area. In her opinion, translanguaging as a pedagogical practice can be utilized by bi/multilinguals (even monolinguals), and this can maximize their communicative potential by using aspects, features, and modes of various languages. Hence, she organized the group of doctoral students in City University of New York so as to arrange the design of translanguaging as a pedagogical practice through New York State Initiative on Emergent Bilinguals (NYSIEB) curriculum.

\subsubsection{Translanguaging Strategies in Cunny-Nysieb Curriculum}

As aforementioned, translanguaging is a package of instructional strategies. It refers to a practice of planned and systematic allocation of two languages inside one lesson which helps learner's meaningmaking through interactional communication in a classroom environment (Garcia, 2011). Its pedagogical strategies are designed to (1) scaffold academic content instruction, (2) scaffold academic language development, and (3) affirm emergent bilinguals' identities. Celic and Seltzer (2011) provided a curriculum with practical applications of 29 translanguaging strategies in the classroom ( for the list of these strategies and examples for each see Appendix).These 29 strategies also form the framework of Cunny-Nysieb curriculum (Hesson, Seltzer \& Woodley, 2014) The strategies are gathered under three main titles. These three main titles are 'Strategies for Classroom', 'Strategies for Content-area Development', 'Strategies for Language Development'. Each of those main categories serves for different background knowledge of a learner. 'Strategies for Classroom' provide visual effect of the multilingual classroom for learners and classroom practices and materials help them to active their language repertoires. 'Strategies for Content Area Development' are more about reading and writing, in other words, literacy skills. As Makalela (2015a) demonstrated, multilingual reading practices, for instance, promote more critical thinking, and consequently, more elaborated meaning construction. Lastly 'Strategies for Language Development' are the ones directly linked to language learning and development on the level of vocabulary and syntactic structures of multi languages.

\subsubsection{Translanguaging Strategies in Foreign Language Classrooms and its Advantages}

Translanguaging strategies help foreign language learners as well as other learners with the possibility of being able to comprehend, evaluate, synthesize and report on information and ideas using text-based resources, to engage in complex texts, and to write, to explain and to convey real or imaginary experience whether the addressee is a monolingual, bilingual or an emergent multilingual. 
Turnbull (2016) is one of the prominent scholars who disrupted monolingual pedagogies and rejected the use of only target language in foreign language instruction. He supports the idea of using translanguaging in any foreign language classrooms. Additionally, considering this contemporary step of instruction, several scholars suggested that the discursive language practices and the concurrent use of two languages as a pedagogic resource might also support students' learning in the foreign language classroom. For instance, Hornberger and Link (2012b) described a case of university students at a teacher training program of the University of Limpopo in multilingual South Africa where students are fostered to freely translanguage between many local languages through writing in order to understand their class readings in English as foreign language. The research also showed that translanguaging with its strategies can eliminate communication barriers while developing students' additional language competencies. Celic and Seltzer (2011), on the other hand, highlighted the friendly atmosphere translanguaging creates in the classroom and its potential to provide respect and tolerance to other languages and cultures. In another setting, Jiménez and colleagues' work (2015), which was conducted in middle school, could be an extraordinary instance for translanguaging strategies in foreign language area. Here, it was explored that how strategic translation in a foreign language classroom can promote students' reading comprehension, and more specifically, their understandings about language. On the other hand, by using a quantitative approach, Bin Tahir, Saidah, Mufidah, and Bugis (2018) conducted a research to measure the effect of TL approach in teaching Arabic (as a foreign language) reading comprehension of 64 students of Indonesian Education Department in Iqra Buru University. Similar to the previous ones these scholars also found that the use of translanguaging in learning Arabic reading comprehension improves the students' ability of reading comprehension. Accordingly, Esquinca, Araujo, and Piedra (2014) proved the appropriateness of these strategies in their three-year ethnographic work and concluded the positive effect of translanguaging strategies specifically in the comprehension of content knowledge. Specifically, for written product, Canagarajah (2011a) used TL as a translingual strategy to support a Saudi Arabian learner's foreign language in her writing. TL opened up an opportunity for writing, and allowed the learner use both English and her native language, Arabic, to endorse her themes in writing. This type of free writing allowed for a thoughtful, and more developed writing.

Within these regards above, TL strategies offer many advantages for the future of bi/multilingual education. Bilingual users are freed from the framed structures that limit their understanding each other and discovering the common features of their unique language repertoire. Therefore, a foreign language curriculum including learning strategies (like multilingual reading or using the bilingual dictionary for vocabulary training) should always be initiated (Turnbull, 2016).

Translanguaging serves three essential functions for learners. These are (1) participation to the class (2) elaboration of their ideas and (3) raise of questions (Garcia \& Leiva, 2014). With these three main functions, the use of translanguaging strategies support both metalinguistic awareness of the translanguagers and their critical language awareness. Martin-Beltrán's research could be an example for such power of translanguaging in the life of learners (2014).

Lastly for the teachers' side, translanguaging provides benefits for both participants of the learning environment; learners and teachers. As García, Johnson, and Seltzer (2017) states, translanguaging puts the teacher into a position of co-learner who learns from learners' not only language but also cultural practices.

\subsubsection{Research Questions}

This study was conducted in a foreign language classroom of an Anatolian high school where German is second foreign language of learners in their learning process and the teacher of the classroom 
knows both German and English, which enables her to use both languages in class. With the research the questions to be answered are as follows:

1. Does the teacher implement TL strategies? If so, what kind of TL strategies does she implement in her SFL classroom?

2. How does the teacher allocate these strategies in German (SFL) classes? Deliberately or not?

3. For what purposes do the learners respond to these strategies?

\section{Method}

\subsection{Research Setting and Participants}

Specifically, for this study, due to the difficulty of finding convenient participants, the participants of that research were purposefully chosen. Participants are a German foreign language teacher and students of an Anatolian high school classroom in which English language is taught as second foreign language (although it is the first foreign language of the students) and the German language is provided as first foreign language. Reasons behind this chosen environment is that the teacher knows both English and German and the students have already scored high proficiency in English language. This fact allows for both sides to follow translanguaging practices in two ways, from German to English or vice versa. The total number of the students in the class was 29.

\subsection{Data Collection Instruments and Procedure}

The current study employed ethnographic perspectives that was combined with a top-down theorydriven approach. For Tracy (2013), "researchers who use ethnographic methods primarily opt for engaging in participant observation and field interviewing from a variety of different contexts" (p.25). Compatible with what Tracy states, the data collection of this study was primarily done through observation by using a checklist and semi-structured interviews in a friendly conversation with the German teacher of the 10th graders.

\subsubsection{Observation}

The main data source for the presented research is observation which was conducted with an adapted checklist from the CUNY-NYSIEB curriculum (see Appendix). The reason for the preference of this specific checklist was that this curriculum was the most comprehensive one designed using translanguaging strategies and there is no curriculum specifically designed for multilingual foreign language classrooms when this study was conducted Actually, the curriculum is designed with 29 strategies which serve for translanguaging practices in bilingual classrooms. However, in this study, out of the 29 strategies, 27 strategies were used in the observation checklist. After the piloting of the checklist before the 23- hour observation start, the two strategies ('TL with Interactive Writing' and 'TL with 'Language Experience Approach") were eliminated as it was understood that these strategies are specifically designed for emerging primary school writers or the ones taking alphabet training.

The researcher participated minimally 23 -hour class observations. The participated classes were 40 minutes long. Every time, the researcher entered the classroom with a new sheet of checklist and filled it with any kind of strategies once they were seen in the duration of instruction. The researcher watched each class carefully and jotted down field notes, as well. 


\subsubsection{Interviews}

Since interviews as a data collection tool a variation in meaning on the same topic or event through different kinds of questions (Emerson, Fretz and Shaw, 1995; Emerson, Fretz \& Shaw 2001), this study used interview as a second main data collection instrument. For the best result of a semi-structured interview, researchers need an interview schedule (protocol) which is a list of issues a researcher would like to cover. Creswell and Miller (2000) claimed that interview protocol reminds researchers of their aims and themes; however, it does not restrict them as researchers. Thus, in this research, the researcher utilized interview protocols in each interview so as to promote the understanding of both the research context and the steps that should be followed.

Three interviews (before, during and after the observation) were carried out and each of these lasted about 30 minutes. The interviews were informal, semi-structured and carried out in a conversational style. The voluntarily participated teacher had choices to complete the interview in English, German or in Turkish. She chose Turkish for the interviews. The interviews included both experiential questions about the teacher's former instruction, and hypothetical questions based on some scenarios in which the informant was asked to share what she would do in some particular classroom situations. The main goals of the first interview (before observation) were to gather demographic information about the teacher and to understand teacher's experience about multiple language instructions. The goals of the second interview (during observation) were to obtain the teacher's opinion about translanguaging strategies and how much she became aware of the strategies after the first interview. The last interview was conducted in the following week after the process of observation ended. It was comprised of only 5 questions. These questions again served to understand if there is voluntarily utilization of TL strategies by the teacher (deliberately or not).

To sum up, interviewing the teacher three times serves three main purposes. These are to infer whether the teacher is aware that she utilizes both languages; whether she uses translanguaging strategies deliberately in a planned manner or spontaneously; and whether she would like to implement more translanguaging strategies in her future foreign language teaching process.

\subsection{Data Analysis Procedure}

Following the strategies on checklist in each visit day, the observed strategies have been analysed according to the deductive analysis, as they had several head titles including the names of each strategy. For interviews, in the study, descriptive coding aimed to capture the friendly conversation between the participant and the researcher. The researcher then developed sub-codes for some major codes, which evolved into categories and themes. The selected samples were coded in order to reach consensus about the descriptions of codes, and the unclear codes were flagged to discuss at monthly research meetings with the supervisor of the study and with peer-coder, as well. The interview data have been analysed through inductive method by re-reading the data over and over again with the codes.

\section{Results}

\subsection{Types of Translanguaging Strategies Used in Class}

In this study, the findings from all field notes have been checked through the checklist which was adjusted and calibrated to the second foreign language classes by using 27 adapted TL strategies of NYSIEB curriculum. From this curriculum, the vocabulary, syntax-based strategies and the multilingual ecology are the strategies which have been primarily implemented in the observed SFL classes. In contrast, the collaborative and writing-based activities are hardly being used. This kind of writing 
activities are rarely preferred by the teacher, and when they are preferred, the teacher has not initially opted for multilingual writing on the activities. Writing activities are completed in a monolingual way.

The intense flow of TL strategies in the second foreign language classroom environment is mainly based on the spoken language, and mostly preferred ones are vocabulary-based strategies as it is seen on Table 2.

Table 1. Lists of TL Strategies Observed and their Occurrences

\begin{tabular}{|c|c|}
\hline Strategies for Classroom & Occurrence \\
\hline \multicolumn{2}{|c|}{ A. Multilingual Ecology } \\
\hline 1. Community Study & 5 times \\
\hline 2. A Multilingual Learning Environment & 88 times \\
\hline \multicolumn{2}{|c|}{ B. Instructional Foundations } \\
\hline 1. Integrated Instruction & 46 times \\
\hline 2. Designing Unit around Multilingual Products & 12 times \\
\hline \multicolumn{2}{|c|}{ C. Translanguaging Resources } \\
\hline 13. Internet as Multilingual Source & 1 time \\
\hline 14. Using Multilingual Texts & 12 times \\
\hline Strategies for Content- Area Development & Occurrence \\
\hline \multicolumn{2}{|c|}{ A. Content-area \& Reading Instructions } \\
\hline 1. Building Background with Preview/ View/ Review & 3 times \\
\hline 2. Multilingual Research & 1 time \\
\hline Strategies for Language Development & Occurrence \\
\hline \multicolumn{2}{|c|}{ A. Vocabulary } \\
\hline 1. Multilingual Word Walls & 45 times \\
\hline 2. Cognate Charts & 37 times \\
\hline 3. Four-box Graphic Organizer and Frayer Model & 13 times \\
\hline 4. Vocabulary Inquiry across Languages & 48 times \\
\hline \multicolumn{2}{|c|}{ B. Syntax } \\
\hline 1. Sentence Building & 34 times \\
\hline 2. Transfer & 42 times \\
\hline
\end{tabular}

Under the name of 'Multilingual Ecology' as a part of 'Strategies for Classroom', which is about the learning environment with its visual space and classroom setup, the learning environment of this study could be called as a one which has multilingual ecological properties. As the designers of the CunnyNysieb curriculum demonstrated, most of the interactions in the class initially help creating a 'Multilingual Learning Environment'. If the use of signals and greetings in another language, or even the transitions of a first foreign language are welcomed in the class, the teacher achieves the 'Multilingual Learning Environment' (Celic\& Seltzer, 2011) Accordingly, in the observed classroom, the teacher always creates a multilingual environment even when someone come out of the classroom. As can be seen in Extract 1, the teacher greets a school worker who comes in during class first in English and then in German.

Extract 1 (2nd Term Observation)

OC: At that time the door was knocked, and the school worker entered to the class.

Worker: Good morning, hocam! 


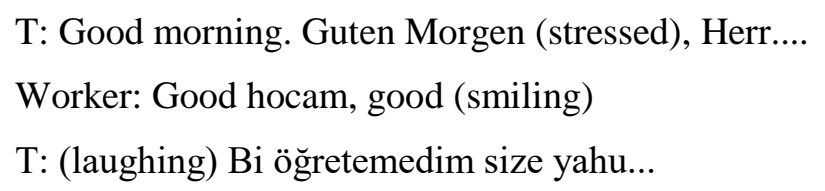

Greeting the class first in English and then in German is a highly occurring practice for this language classroom. As another example for a multilingual environment, while the teacher instructs about the directions, she turns on the smart board and shows the examples of English and German signs that are positioned on a street. First, she lonely compares the signs on both pictures searching in the Internet, murmuring until she finds similar signs in English and German. Later on, she shows different signs in English and German.

Although learning objectives are not planned for the practice of translanguaging in school, course book or the teacher's daily planning level, various instances of 'Integrated Instruction' are observed in the classroom, one of which is exemplified with the following observation notes.

Extract 2 (2nd Term Observation)

T: Ja, Schau bitte die Fotos an. Was machen sie? (just a second) What are they doing?

S17 and S4: Dance (together)

OC: $\mathrm{S} 17$ is the one who contributed the least during my observation.

T: ok, Dance auf Deutsch?

S9: Tanzen, hocam

T: Tanzen, genau meine liebe, was noch wir haben in foto zwei nummer? Was noch? (curiously) [She is both answering and creating the hand-made word wall on the left side of the white board]

S6: Essen?

T: aber da hinten? Auf dem background?

S6: Sleep?

$\mathrm{T}$ : nein, what are they doing?

S3: tired? aber wie sagt man auf Deutsch, hocam?

T: wie? (turning to the others)

S4: müde.

$\mathrm{T}:$ ja, super!

By 'designing a unit around multilingual products, a teacher can encourage TL by creating a product in a multilingual way for a specific purpose. The online platform and additional exercises of the Schritte course book that have been used in this research environment includes those productive multilingual tasks a lot. At the same time, in the classroom environment, these 'multilingual products' are observed. For example, the observed teacher heavily prefers using multilingual handouts and worksheets.

In this study, during the whole observation, the researcher encounters many samples of the 'multilingual texts', though these texts are not so long or generally not more than two sentences. However, the teacher rarely utilizes 'Internet as Multilingual Strategy'. During the visit process to the classes, it was seen once when she assigned a search work about the day's topic. She wanted the students to find a sample monster or a cartoon character in any language and translate the monster's features into German language. The use of internet in the classroom was what the teacher claimed as a teaching 
resource, but during observation the above stated time was the only occurrence as a translanguaging practice.

Through 'Preview-View-Review' strategy in reading activities the shaky content and language knowledge of students could become more organized and stronger. With 'Preview-View and Review' Strategy, a teacher makes brainstorming, make connections between the topic, and share prior knowledge so as to cover the new subject for emergent bilinguals. The transfer of languages could be in the form of $\mathrm{L} 2 \rightarrow \mathrm{L} 2 \rightarrow \mathrm{L} 3, \mathrm{~L} 1 \rightarrow \mathrm{L} 2 \rightarrow \mathrm{L} 3$ or $\mathrm{L} 1 \rightarrow \mathrm{L} 2 / \mathrm{L} 3 \rightarrow \mathrm{L} 3$. Presenting the content in SFL could include a mini-video/ audio or a reading text etc. In review stage, whole class can discuss, summarize and analyse the topic in any language they want (Celic and Seltzer, 2011). As an example, for this study, Extract 3 demonstrates that the teacher would like to build background with 'Preview-View-Review' strategy through speaking on the new reading text by activating the productive skills of the learners as follows:

\section{Extract 3 (1st Term Observation)}

T: [T went back to her desk and started the new unit (unit 11- In der Stadt Unterwegs). All the qs about the first picture were asked in German and Turkish. Some English words were used, too.] ... Bu üniteden beklentiniz nedir, çocuklar? (starring to SS) Hangi konuları işleyeceğiz sizce?

S9: Dön sağa, düz git, adres tarifleri gibi [While he is checking the pictures on the book]

\section{S17: Hocam yer yön bulacağız sanki}

T: Genau, Weiss das ihr schon? [Many of the students directly turn the pages and check the contexts. However, they do not want to see the eyes of teacher so as not to be asked any qs by the teacher]

WC: <no response>

T: auf English?

WC: "directions" [some of them are shouting]

T: Jawohl, aber ,directions heisst auf Englisch. Auf Deutsch, das heisst 'Weg Beschreibung'.

Generally, the teacher starts her mini- reading passages in mother language, and sometimes with first foreign language and then she describes the content in the target language. Later on, the teacher goes on by using all languages in an intertwined way.

Inferring from the current findings, in this foreign language classroom, under the type of 'Strategies for Language Development', there are abundance of examples about 'word walls', but they are not on a wall or a bulletin board. In contrast, 'word walls' are used as a strategy by the teacher on the board while presenting vocabulary. In about each class, the teacher rigorously writes the words in both languages on the top left side on the board in order to enlarge the vision of the learners and provides them resolution in first foreign language for scaffolding the new word in second foreign language- German.

The chart-based reflection or a panel for 'cognates' could not be encountered by the researcher in this study. However, there are numerous instances of verbal use of 'cognates'. For instance, Extract 4 below could be the sample of the use of cognates verbally. Thus, for the purposes of present research, these instances have been counted as 'Cognate Charts' strategy of translanguaging.

According to findings related to 'Four-box Graphic Organizer and Frayer Model', organizers are not given in printed-out paper format. Instead, the teacher separates the board as four parts and draws her 
organizer by hand and fills the gaps by picking the answers from the students while presenting vocabulary.

'Vocabulary Inquiry across Languages' means digging deeply into student's different languages in order to find linguistic similarities and differences among word origins, sounds, usage and expressions. The following extract illustrates us how the teacher uses many sorts of words to make the targeted word remembered in English and to teach new content in German:

\section{Extract 4 (1st Term Observation)}

T: Was haben wir kennen? Was ist ,flughafen"?

IS: "airport." [At that time, one of the students who was front row, shouted]

T: Genau! [T accepted the answer sincerely, then $T$ asked again]

was ist denn da" Deutsche Bahnhof"?

S10: Tren?

T: Evet, super. [The class was going on in Turkish after that. T made some explanations about the transportation in Germany. Then she made comparison with English words and showed on the board]

T: was ist U-Bahn? [asked again for each word]

S5: I think, das heisst Metro.

T: Was heisst es aber auf Englisch denn da...?

WC: Subway (screamed all together)

'Sentence Building' strategy teaches both emergent and proficient learners how to construct increasingly complex sentences. Initially, the teacher can give learners a basic sentence and show them how they can add a particular grammatical structure to make it more complex. Extract 5 clearly represents this strategy:

\section{Extract 5 (1st Term Observation)}

T: Wer weisst du ,von '? İngilizce'deki "From" gibi. „I am coming from Germany"

S2: Türkçedeki -den, -dan gibi değil mi, hocam?

T: Jawohl, eine Muster? Example var mı? Aynı ingilizcedeki gibi isimden sonra bakin (pointing on the board)

S16: Hocam bu olur mu? < silence in the class> „Ich komme von der Turkei“

T: ,Ich komme aus der Türkei‘ olmalı, çünkü Almancada 2 tane ,from‘ war.

Burada ki "den-dan" aus olmalı, meine liebe. [The bell was heard]. Ich komme von der Ecke auf Englisch [interrupting]

S12: 'I come from...' neydi ya?

\section{S16: Corner}

The replication of rules from first language to second language is mainly called 'language transfer'. There is a common belief that knowledge and understanding of first foreign language has a great impact on the understanding of second foreign language. This belief supports the idea that learners might transfer grammar, vocabulary, syntax, semantics, spelling, morphology, pronunciation, structure, and culture to second language. The following extract clearly shows how beneficial it is to transfer between languages to let the learners understand and use a form in another foreign language, which is German in this case. 


\section{Extract 6 (1st Term Observation)}

T: Was haben wir auf dem bild 2? [make it detailed by adding] Timo sagt, Koko sollen zu hause.

S1: Sie sollen zu hause.

T: Genau, aber was ist ja aber „sollen“, denn? [asked curiously]

WS: <silence>

T: Sollen ist "must" auf Englisch. Was ist 'sollen' meine Lieben?

S2: zorunluluk bildirir.

S1: -meli -malı değil miydi ya?

T: Genau. Koko (name of Papagei) sollen zu hause bleiben.

Regarding the first research question, the observation data showed that translanguaging strategies are highly used in this German class by the teacher and the students respond to these strategies, but whether the teacher use these strategies deliberately or not is the other concern of this research, which will be answered in the following section.

\subsection{Undeliberate Use of Translanguaging Strategies by the Teacher}

After gathering of the demographic information via the 1st interview, the researcher conducted the 2nd and the 3rd ones successively. Via the 2nd interview, it seemed as if the class teacher is willing to implement strategies in her classes but it was clear that she did not know what translanguaging is. However, through the last interview, the researcher crosschecked that the teacher unintentionally utilizes TL strategies. In addition, the researcher took field notes and diary entries into account in order to precisely clarify the use of TL strategies is undeliberate.

Taking long conversations with the teacher and scanning the notes, the researcher noticed that she naturally uses English and TL strategies without any knowledge of the theory of translanguaging. The following extract is one example for this result:

\section{Extract 7(3rd Interview)}

R: As I observed you are implementing English nearly in all subjects by using some strategies. How would you describe those strategies?

T: Uhm..mmm

$\mathrm{R}$ : If you give a name to them, what would it be?

T: It may be an association. Uhm...mmm or it could be the reconstruction of the knowledge (thinking). Sometimes I may use English in the introduction to remind the topic better. Apart from that it could be a way from the known through the unknown without frustration of SS. I prefer these strategies, <clear-throat> but I couldn't give the specific name for them right now.

Considering the interview data, it is true that the teacher uses translanguaging undeliberate and without clear planning of translanguaging strategies. Still, she is eager to use the strategies in classroom practices. Even though, the teacher strongly refuses the overuse of English language in the class hours of German language, she immediately changes her idea during the interview when she hears more scenarios from the researcher on translanguaging. When it comes to the difficulty of German language, especially for the low-level students who have not sufficient word storage to speak, the teacher approves the idea of using first foreign language- English in German classes by giving positive integrated 
feedback in both languages. Although she does not have an opinion about the implementation of translanguaging and its strategies, by skimming the given scenarios, the teacher approves the idea that using these kinds of strategic techniques is quite fruitful in the teaching process. As the teacher has answered in her last interview, though she does not have an idea about what translanguaging is, she wants a curriculum, a planned way so as to activate the learners' full linguistic repertoires.

\subsection{Learners' Responses to TL Strategies}

Though responses to TL strategies by the students are mainly given in question form, and these responses seem as if they were serving for the purpose of raising question at first sight, all these questions of the students in the class also intent participation to the class, except one which was totally irrelevant to class content in the day when the observation was being held.

The least used response is for the purpose of elaboration of ides, which is necessary for critical thinking and getting the gist of any text. The reason behind this result could depend on the fact that the course content of this German class consists of short texts and sentence level reading rather than long passages, and the teacher used sentence by sentence translation technique for the texts.

To exemplify students' responses, in the following observation data, the teacher asks for the meaning of a German word, and there appeared no answers in the classroom for a long time; however, in a sudden, one of the students screams the word in English. S10 is likely to be able to join the class using English.

Extract 8 (Second Term Observation)

T: Kirli ne demek? Auf Deutsch bitte?

S10: <long-pause> (then) Dirty?

T: Nein, auf Deutsch bitte!

S1: (in a sudden, student from the back row) Schmützig, şimdi hatırladım, unutmamışım hocam.

T: Danke, S1. Schmutzig [correcting her answer] Yüksek sesle bir daha söyle bakayım.

\section{Discussion}

Firstly, the flow of strategies in second foreign language classroom environment is mainly based on the spoken language and mostly for vocabulary-based strategies. Therefore, the strategies do not overreach the word-based interaction through reading and some listening activities. Also, in general, the analysis of the interviews and checklists indicated that the teacher mainly benefits from 'Strategies for TL Classroom' and 'Strategies for Language Development' and she barely prefers using Strategies for 'Content-Area Development'. On the other hand, several strategies under different head titles were not apparently observed during the visit days of the researcher, such as 'Content-area Writing Instructions', 'Multilingual Listening Center', 'Language Portfolio', etc. In addition to those, some strategies, like 'Community Study' or 'Internet as Multilingual Resources', are slightly utilized because of the unpreparedness due to heavy class hours of the teacher, lack of materials and last but not least the low German levels of the students in the second foreign language classroom.

Moreover, the 'integrated feedback' is such an unexpected finding for the first research question when the observation has reached the focused segment after a while. This strategy is not included in the observed checklist though it is mostly seen in the teaching of second foreign language. The teacher fosters the students with numerous mixed language feedbacks, as well as first language. By giving 
integrated feedback in first and second foreign language together, such as ' $\mathrm{ja}$, but that's not the full answer, machen sie bitte andere übung', how tolerant the teacher to her students is clearly observed.

Secondly, especially interview results obviously show that the teacher willingly instructs in both languages though she has not had prior knowledge about translanguaging strategies, so, she undeliberate allocates translanguaging strategies. Frankly, through the help of last two interviews, it was made sure that the teacher unintentionally uses English through translanguaging strategies. The findings gathered from the study also showed that languages might work together in the classroom, rather than competitively. According to the teacher, foreign language teaching environment is a place so as to encourage translanguaging strategies more. Hence, she explained in the interview that she needs more mastery in English. In other words, the teacher wants to improve her English and would like to take additional skill-based courses to practice translanguaging strategies. Over and above, she expressed that activating both languages in a classroom is an innovation in this century.

Learners, in the current study, are not totally free to use their both languages in every position, such as on exam or quiz paper, but at least during the class time, they have expressed themselves freely. Due to the free use of English in class time, the students' voluntary participation in the class and raising questions are apparently observed. In addition to that, while the students have been doing their homework, or have been in charge of any kinds of assignments, they have initially used English as an assisting language, although on formal documents they have not been allowed to do so.

\section{Conclusion}

All the findings obtained during this research can contribute to the betterment of foreign language education development in Turkey. In this regard, the following statements describe the main implications to improve foreign language education in Turkey:

Though translanguaging has been practiced limitedly with the aid of specific curriculum, in particular, for minorized students, some scholars thought that there is no certain instruction to calibrate the class environments and thus, they announced that there were no concrete and specific set of teaching strategies that are generalizable across all classroom settings for this practice (Canagarajah, 2011b; Hornberger \& Link, 2012a). The majority of these studies represented the idea that the acts of translanguaging were not elicited through conscious pedagogical strategies by educators. But for many research reports, scholars also admitted that the implementation of this practice is an appealing task, and it allows multilinguals to use a fuller range of linguistic practices so as to develop rich and wide range of communicative repertoires (García, 2009; Hornberger \& Link, 2012b). Translanguaging strategies could easily be established in foreign language classrooms when teachers have a specific curriculum including equal design of both languages through numerous strategies like in bilingual educational programs. Thus, both teacher development programs and the curriculum of multilingual language teaching contexts could be redesigned including translanguaging strategies. Secondly, in the context of multilingualism in the world and in Turkey, monolingual or passive bilingual teachers should be supported and encouraged to gain awareness for the importance of translanguaging and to improve their language teaching career towards the use of blended instructions. In accordance with the previous suggestion, Garcia and her doctoral students recognized that much work had to be done in the teaching profession and the Dynamic System Theory, in other words, translanguaging had to be converted into utilizable knowledge providing practitioners with concrete guidance on how to incorporate a variety of language practices into classroom teaching (García, 2011; Celic \& Seltzer, 2011). Then, they described the challenges in professional learning and suggested practices for practitioners to create multilingual learning environments for language-minoritized children (Celic \& Seltzer, 2011). On the other hand, 
language learners are in need of supplementary materials incorporating translanguaging like worksheets, handouts, bilingual dictionaries, online materials, etc. The design of language teaching environments may also include more multilingual bulletin boards to activate all languages and foster new language(s) learning. Heller (2007) explained that to be able to access to language that learners have, teachers need to access some resources which are also valuable for them and so, these multilingual resources allow for competition over access and unequal distribution in classrooms. She also asserted that with the assistance of multilingual resources in the class, learners can produce joint activities and shared space with interlocutors and teachers to explain their values, beliefs, and have a chance to expose their identities by using their target, heritage or home language. Also, they can easily find a way to interact and negotiate with others with the lack of shyness and hesitation. The present study has contributed to the limited literature on translanguaging with the exploration of German as a second foreign language class in the local context of Turkey as the sample. Despite its rich data, a longitudinal study could be conducted to see teachers' proficiency of using translanguaging strategies from a broader perspective like in the research of Lewis et al. (2012) who reported on a 5-year longitudinal research about common use of translanguaging in primary schools in Wales. By running a combination of observation and standardized measures he introduced academic advantages of translanguaging to develop students' bilingualism (as cited in Garcia et al., 2017). Moreover, this study could be replicated with different participants, in different contexts of language classroom since this practice (translanguaging) could be utilized with different levels of emergent language learners learning different languages as Pontier and Gort (2016) did with preschool teachers of Spanish and English and Li and Zhu (2013) did with university level learners. Lastly, translanguaging as an emergent field of language teaching and learning awaits other researches, and these studies can also be conducted as experimental studies or using a survey or scale. For example, Makalela (2015b) demonstrated the beneficial side of the 'Content-Area Development' strategies by using descriptive statistics using pre-and post-tests. By doing so, researchers can even evaluate the effect of translanguaging on the success and anxiety or motivation levels of learners while minimum two or more languages are used together in classrooms.

\section{Ethics Committee Approval}

The authors confirm that the approval was obtained from İstanbul Directorate of National Education Written Permission (Approval Date and No: 10.10.2017-59090411-44-E.16248778).

\section{References}

Baker, C. (1995). A parents' and teachers' guide to bilingualism. Clevedon: Multilingual Matters.

Becker, R. A., Chambers, J. M., \& Wilks, A. R. (1988). The new language. Pacific Grove, CA: Wadsworth \& Brooks.

Becker, A. L., \& Mannheim, B. (1995). Culture Troping: Languages, codes, and texts. In D. Tedlock \& B. Mannheim (Eds.), The dialogic emergence of culture (pp. 237-252). Chicago, IL: University of Illinois Press.

Bin-Tahir, S. Z., Saidah, U., Mufidah, N., \& Bugis, R. (2018). The Impact of translanguaging approach on teaching Arabic reading in a multilingual classroom. Ijaz Arabi Journal of Arabic Learning, 1(1), 20-27. doi: 10.18860/ijazarabi.v1i1.4932

Blackledge, A., \& Creese, A. (2014). Heteroglossia as practice and pedagogy. In A. Blackledge \& A. Creese (Eds.), Heteroglossia as practice and pedagogy (pp.1-20). Dordrecht: Springer. 
Brady, A., \& Shinohara, Y. (2000). Principles and activities for a transcultural approach to additional language learning. System, 28(2), 305-322. https://doi.org/10.1016/S0346-251X(00)00014-2

Canagarajah, S. (2011a). Code-meshing in academic writing: Identifying teachable strategies of translanguaging. The Modern Language Journal, 95(3), 401-417. https://doi.org/10.1111/j.15404781.2011.01207.x

Canagarajah, S. (2011b). Translanguaging in the classroom: Emerging issues for research and pedagogy. Applied Linguistics Review, 2(2011), 1-27. https://doi.org/10.1515/9783110239331.1

Canagarajah, A. S. (2013). Critical academic writing and multilingual students. Ann Arbour, MI: University of Michigan Press.

Celic, C., \& Seltzer, K. (2011). Translanguaging: A CUNY-NYSIEB guide for educators. New York, NY: CUNY-NYSIEB.

Cenoz, J. (2009). Towards multilingual education: Basque educational research from an international perspective. Bristol: Multilingual Matters. https://doi.org/10.21832/9781847691941

Charalambous, C., \& Rampton, B. (2012). Other language learning, identity and intercultural communication in contexts of conflict. In J. Jackson (Ed.), Routledge handbook of intercultural communication, (pp.195-210). London: Routledge.

Creswell, J. W., \& Miller, D. L. (2000). Determining validity in qualitative inquiry. Theory into Practice, 39(3), 124-130. https://doi.org/10.1207/s15430421tip3903_2

Creese, A., \& Blackledge, A. (2010). Translanguaging in the bilingual classroom: A pedagogy for learning and teaching. Modern Language Journal, 94(1), 103-115. https://doi.org/10.1111/j.15404781.2009.00986.x

Emerson, R. M., Fretz, R. I., \& Shaw, L. L. (1995). Writing ethnographic fieldnotes: Chicago guides to writing, editing. and publishing. Chicago, IL: University of Chicago Press. https://doi.org/10.7208/chicago/9780226206851.001.0001

Emerson, R. M., \& Fretz, R. I., (2001). Participant observation: Handbook of ethnography (pp. 352368). London: Sage.

Esquinca, A., Araujo, B., \& de la Piedra, M. T. (2014). Meaning making and translanguaging in a twoway dual-language program on the US-Mexico border. Bilingual Research Journal, 37(2), 164-181. https://doi.org/10.1080/15235882.2014.934970

García, O. (2009). Emergent bilinguals and TESOL: What's in a name? Tesol Quarterly, 43(2), 322326. https://doi.org/10.1002/j.1545-7249.2009.tb00172.x

García, O. (2011). Bilingual education in the 21st century: A global perspective. Hoboken, NJ: John Wiley \& Sons.

García, O., Johnson, S. I., \& Seltzer, K. (2017). The translanguaging classroom: Leveraging student bilingualism for learning. Philadelphia, PA: Caslon. https://doi.org/10.1080/09500782.2016.1255224

García, O., \& Leiva, C. (2014). Theorizing and enacting translanguaging for social justice. In A. Blackledge \& A. Creese (Eds.), Heteroglossia as practice and pedagogy (pp.199-216). Dordrecht: Springer. 
García, O., \& Lin, A. M. Y. (2006) Translanguaging in bilingual education. In O. García, A. M. Y. Lin, \& S. May (Eds.), Bilingual and multilingual education (pp.117-130). Switzerland: Springer. doi: 10.1007/978-3-319-02258-1_9.

García, O., Lin, A. M. Y. \& May, S. (Eds.) (2017). Bilingual and multilingual education (3 ${ }^{\text {rd }}$ ed.), Switzerland: Springer.

García, O., \& Sylvan, C. E. (2011). Pedagogies and practices in multilingual classrooms: Singularities in pluralities. The Modern Language Journal, 95(3), 385-400. doi: 10.1111/j.1540-4781.2011. 01208.x 0026-7902/11/385-400

García, O., \& Wei, L. (2014). Translanguaging: Language, bilingualism and education. Dordrecht: Springer.

Hammarberg, B. (2010). Processes in third language acquisition, Edinburgh: Edinburgh University Press Ltd.

Hammarberg, B. \& Williams, S. (2009). A study of third language acquisition, In B. Hammarberg (Eds.) Processes in third language acquisition (pp. 17-28), Edinburgh: Edinburgh University Press.

Heller, M. (2007). Bilingualism as ideology and practice. In M. Heller (Ed.) Bilingualism: A social approach (pp. 1-22). New York, NY: Palgrave Macmillan.

Hesson, S., Seltzer, K., \& Woodley, H. H. (2014). Translanguaging in curriculum and instruction: A CUNY-NYSIEB guide for educators. New York, NY: CUNY-NYSIEB.

Hornberger, N. H., \& Link, H. (2012a). Translanguaging in today's classrooms: A biliteracy lens. Theory into Practice, 51(4), 239-247. https://doi.org/10.1080/00405841.2012.726051

Hornberger, N. H., \& Link, H. (2012b). Translanguaging and transnational literacies in multilingual classrooms: A biliteracy lens. International Journal of Bilingual Education and Bilingualism, 15(3), 261-278. https://doi.org/10.1080/13670050.2012.658016

Jiménez, R. T., David, S., Fagan, K., Risko, V. J., Cen, M., Pray, L., \& Gonzales, M. (2015). Using translation to drive conceptual development for students becoming literate in English as an additional language. Research in the Teaching of English, 49(3), pp. 248-271.

Jørgensen, J. N., Karrebæk, M. S., Madsen, L. M. \& Møller, J. S. (2011). Polylanguaging in Superdiversity. Diversities, 13(2), pp. 23-37.

Lewis, G., Jones, B., \& Baker, C. (2012). Translanguaging: Origins and development from school to street and beyond. Educational Research and Evaluation, 18(7), 641-654. https://doi.org/10.1080/13803611.2012.718488

Li, W., \& Zhu, H. (2013). Translanguaging identities and ideologies: Creating transnational space through flexible multilingual practices amongst Chinese university students in the UK. Applied Linguistics, 34(5), 516-535. doi: 10.1093/applin/amt022

Madsen, L. M. (2014). Heteroglossia, voicing and social categorisation. In A. Blackledge \& A. Creese (Eds.), Heteroglossia as practice and pedagogy (pp.41-58). Dordrecht: Springer.

Makalela, L. (2015a). Translanguaging as a vehicle for epistemic access: cases for reading comprehension and multilingual interactions. Per Linguam, 31(1), 1529. https://doi.org/10.5785/31-1-628 
Makalela, L. (2015b). Moving out of linguistic boxes: The effects of translanguaging strategies for multilingual classrooms. Language and Education, 29(3), 200-217. https://doi.org/10.1080/09500782.2014.994524

Martin-Beltrán, M. (2014). “What do you want to say?” How adolescents use translanguaging to expand learning opportunities. International Multilingual Research Journal, 8(3), 208-230. doi: $10.1080 / 19313152.2014 .914372$

Mignolo, Walter D. (2000). Local histories/global designs. Coloniality, subaltern knowledge and border thinking. Princeton, NJ: Princeton University Press. doi: 10.1016/S0261-3050(00)00042-5

Otheguy, R., García, O., \& Reid, W. (2015). Clarifying translanguaging and deconstructing named languages: A perspective from linguistics. Applied Linguistics Review, 6(3), 281-307. doi: 10.1515/applirev-2015-0014

Otsuji, E., \& Pennycook, A. (2011). Social inclusion and metrolingual practices. International Journal of Bilingual Education and Bilingualism, 14(4), 413-426. doi: 10.1080/13670050.2011.573065.

Pontier, R. \& Gort, M. (2016). Coordinated translanguaging pedagogy as distributed cognition: A case study of two dual language bilingual education preschool co-teachers' languaging practices during shared book readings. International Multilingual Research Journal, 10(2), 89-106. https://doi.org/10.1080/19313152.2016.1150732

Rampton, B. (2011). From 'multi-ethnic adolescent heteroglossia 'to 'contemporary urban vernaculars'. Language \& Communication, 31(4), 276-294. doi: 10.1016/j.langcom.2011.01.001

Shohamy, E. G. (2006). Language policy: Hidden agendas and new approaches. New York, NY: Routledge. doi: 10.4324/9780203387962

Tracy, S. J. (2013). Qualitative research methods. West Sussex: Wiley-Blackwell.

Tucker, G. R. (1998). A global perspective on multilingualism and multilingual education, In J. Cenoz and F. Genesee (Eds) Beyond bilingualism: multilingualism and multilingual education (pp. 3-16). Clevedon: Multilingual Matters. doi: 10.2307/417241.

Turnbull, B. (2016). Reframing foreign language learning as bilingual education: epistemological changes towards the emergent bilingual. International Journal of Bilingual Education and Bilingualism, 1-8. doi: 10.1080/13670050.2016.1238866.

Wei, L. (2011) Moment analysis and translanguaging space: Discursive construction of identities by multilingual Chinese youth in Britain. Journal of Pragmatics, 43, 1222-1235. doi: 10.1016/j.pragma.2010.07.035.

\section{Appendix: List of translanguaging strategies in Cunny-Nysieb curriculum with examples}

\begin{tabular}{|c|c|}
\hline Strategies for Classroom & Examples \\
\hline \multicolumn{2}{|c|}{ A. Multilingual Ecology } \\
\hline 1. Community Study & Looking for signs or announcements \\
\hline 2. Culturally Learning Environment & Writing identity text, cultural relevance rubric \\
\hline 3. A Multilingual Learning Environment & Rules and routines charts \\
\hline 4. Language Portfolio & Language biography or passport \\
\hline \multicolumn{2}{|c|}{ B. Instructional Foundations } \\
\hline 5. Multilingual Language Objectives & Text level or word level etc. \\
\hline 6. Integrated Instruction & Combining reading and writing work together \\
\hline 7. Designing Unit around Multilingual Product & Oral presentation or debates \\
\hline
\end{tabular}




\section{Collaborative Work}

8. Multilingual Collaborative Work: Content Areas Discuss-Reflect-Negotiate content in any

language then share out in L3

9. Multilingual Collaborative Work: Reading Groups

10. Multilingual Writing Partners

Guided Reading or book clubs

11. Multilingual Reading Partners

Brainstorm together in any language and write

in L3- work together to translate

Listen together and discuss in any language

D. Translanguaging Resources

12. Bilingual Dictionaries and Online Translation Tools

13. Internet as Multilingual Source

Picture dictionaries

14. Using Multilingual Texts

15. Multilingual Listening Center

Bilingual research websites

Creating a L2 translation of a L3 text

Oral website translator or audio books

Strategies for Content- Area Development

Examples

\section{A. Content-area \& Reading Instructions}

16. Building Background with Preview/View/ Review

KWL charts

17. Multilingual Research

Conducting interviews

18. Comparing Multilingual Texts

Jigsaw Readings via graphics

19. Multilingual Reading and Responses

Responding to $\mathrm{L} 2$ reading via writing in $\mathrm{L} 3$

B. Content-area \& Writing Instructions

20. TL with Interactive Writing

21. TL with 'Language Experience Approach'

22. TL with Multi-Genre Writing

23. TL with Independent Writing

Phonics charts

Dictate

Postcards and letters in both language

Labeling the languages

Strategies for Language Development

Examples

A. Vocabulary

24. Multilingual Word Walls

Word cards

25. Cognate Charts

Charts of Distance terms etc.

26. Four-box Graphic Organizer and Frayer Model

27. Vocabulary Inquiry across Languages

Models of Farm animals

Word origins or word sounds

28. Sentence Building

B. Syntax

29. Transfer

Introducing a grammatical component

Editing works

\section{Diller arası geçiş stratejilerinden faydalanılarak birinci yabancı dilin (İngilizce) ikinci yabancı dil (Almanca) öğretimindeki yansımaları}

\section{$\ddot{O} \mathbf{z}$}

Bu çalışma dillerarası geçiş stratejilerini belirleyip bu stratejilerin yabancı dil sınıflarında etkinliğini sorgulamayı hedeflemektedir. Bu hedefi gerçekleştirmek üzere 2017-2018 y1l güz ve bahar dönemlerinde bir 10. sinıf Almanca sınıfı gözlemlenmiş ve gözlem öncesinde, esnasında ve sonrasında bu ikinci yabancı dil sınıfının Almanca öğretmeni ile görüşmeler yapılmıştır. The City University of Newyork'ta yapılan çalışmalar temelinde öğretimin yarısının İngilizce yarısının ise diller arası geçiş stratejileri kullanılarak hedef dilde yapılması yabancı dil öğretiminde etkilidir ve yarar sağlamaktadır. Yeni bir uygulama olarak diller arası geçiş stratejileri hem eğitim hem dil eşitliğinin bir parçası olarak kabul edilmektedir. Yabancı dillerin dil sınıflarında katı bir şekilde 
ayrıştırılmasını reddederek diller arası geçiş stratejileri öğretmenlerin bir başka yabancı dil öğretirken birinci yabancı dilin ve hedef yabancı dilin yarı yarıya kullanıldığı bir model uygulamalarına olanak sağlamaktadırlar. Bu güncel çalışmanın sonuçları öğretmenin ikinci yabancı dil sınıfında sözcük ve sözdizim odaklı stratejileri kullandığını ve öğrencilerin bu stratejilerin kullanımına katıldı̆̆ını ve bunu uygulamalara katılmak ve sorular sormak için yaptığını göstermektedir. Özellikle görüşme metinleri göz önüne alındığında öğretmenin bu stratejileri bilmeden ve plansız fakat istekli bir şekilde kullandığı tespit edilmiştir.

Anahtar sözcükler: diller arası geçiş; diller arası geçiş stratejileri; yabancı dil öğretimi; birinci yabancı dil; ikinci yabanci dil

\section{AUTHORS BIODATA}

Gülbin Dağhan- Aslan graduated from İstanbul University German Language Teaching BA Programme in 2013. She received her MA degree in ELT at İstanbul University in 2019. She worked as an English teacher between the years 2013-2019. Currently, she has been working on her book including adaptations and applications of games to teach English as a foreign language.

Gülay Kiray is currently working as an assistant professor at Istanbul University- Cerrahpaşa, ELT Department. She received her master's and doctorate degrees respectively in 2002 and 2011 in ELT. Her primary research interests are curriculum and language teaching materials design, academic writing, teaching and researching language skills specifically literacy skills, and coursebook evaluation. 